\title{
Pengaruh Pembelajaran Model Problem Based Learning Dipadu Team Assisted Individualization terhadap Keterampilan Metakognitif
}

\author{
Din Hadi Shofyan ${ }^{1}$, Aloysius Duran Corebima ${ }^{1}$, Fatchur Rohman ${ }^{1}$ \\ ${ }^{1}$ Pendidikan Biologi-Universitas Negeri Malang
}

\begin{tabular}{l}
\hline \hline INFO ARTIKEL \\
\hline Riwayat Artikel: \\
Diterima: 23-09-2019 \\
Disetujui: $13-05-2020$ \\
\hline
\end{tabular}

\section{Kata kunci:}

problem based learning; team assisted individualization; metacognitive skills problem based learning; team assisted individualization; keterampilan metakognitif

\author{
Alamat Korespondensi: \\ Din Hadi Shofyan \\ Pendidikan Biologi \\ Universitas Negeri Malang \\ Jalan Semarang 5 Malang \\ E-mail: dinhadishofyan333@gmail.com
}

\begin{abstract}
ABSTRAK
Abstract: This study aims to reveal the effect of the PBL model combined with TAI on metacognitive skills. This quasi-experimental research uses a Pretest-Posttest Nonequivalent Control Group Design. Data collection techniques through pretest and posttest. Data were analyzed with the help of SPSS 23 for Windows to determine the effect of the PBL model combined with TAI on metacognitive skills. The results showed that the students' metacognitive skills learned through the PBL model combined with the TAI were significantly higher than through the PBL, TAI and conventional models. The average difference in the PBL model combined with TAI to PBL was $7.38 \%$, PBL combined TAI to TAI was $28.42 \%$, and PBL was combined with TAI to conventional by $29.93 \%$.

Abstrak: Tujuan penelitian ini untuk mengungkap pengaruh PBL dipadu TAI terhadap kemampuan metakognitif. Penelitian jenis kuasi eksperimen ini menggunakan rancangan Pretes-Posttest Nonequivalent Control Group Design. Data didapatkan dari nilai pretes dan postes. Analisis data menggunakan uji ANAKOVA dan LSD. Hasil penelitian menunjukkan, keterampilan metakognitif peserta didik melalui pembelajaran PBL dipadu TAI secara signifikan lebih tinggi dibanding melalui model PBL, TAI dan konvensional. Rerata selisih beda model PBL dipadu TAI terhadap PBL sebesar 7,38\%, PBL dipadu TAI terhadap TAI sebesar 28,42\%, dan PBL dipadu TAI terhadap konvensional sebesar $29,93 \%$.
\end{abstract}

Fokus pembelajaran saat ini adalah memberdayakan keterampilan berpikir tinggi yang merupakan kebutuhan untuk bertahan hidup di abad pengetahuan (Corebima, 2016). Keterampilan berpikir tinggi menjadikan seseorang lebih kritis, kreatif, dan kolaboratif dalam bertindak (Trilling \& Fadel, 2012). Selanjutnya, Zubaidah (2016) menjelaskan bahwa keterampilan berpikir tinggi penting dikuasai siswa agar menjadi pribadi yang mampu menghadapi segala persoalan kehidupan yang muncul. Keterampilan metakognitif merupakan salah satu kemampuan berpikir tinggi yang penting dimiliki peserta didik (Emily \& Michaele, 2012). Keterampilan metakognitif penting untuk mengarahkan setiap proses berpikir siswa dalam belajar (Peters, 2000). Siswa dengan keterampilan metakognitif yang baik menunjukkan prestasi belajar yang baik dalam bidang akademik (Basith, 2014). Keterampilan metakognitif dilaporkan terbukti memengaruhi produk penting pembelajaran meliputi hasil belajar kognitif tinggi dan retensi siswa (Ardila, 2013; Basith, 2014; Fauziyah, 2013; Nurisya, 2017; Usman, 2018).

Fakta menunjukkan bahwa keterampilan metakognitif di Indonesia khususnya kalangan SMA rendah. Penelitian Sholihah, dkk (2015) memperlihatkan keterampilan metakognitif peserta didik SMA Negeri Batu berada pada level can not really, sehingga perlu untuk diberdayakan. Penelitian Aprilia (2013) menunjukkan bahwa keterampilan metakognitif siswa SMAN 1 Rengel, Tuban berada pada kriteria rendah. Selanjutnya, penelitian yang dilakukan oleh Suratno (2010) menunjukkan bahwa keterampilan metakognitif siswa SMA Negeri Jember tergolong rendah. Penelitian lain oleh Nurisya (2017) melaporkan rendahnya keterampilan metakognitif siswa SMAN 7 dan SMAN 9 Malang.

Rendahnya keterampilan metakognitif berdampak pada produk pembelajaran lain yaitu hasil belajar kognitif tinggi. Hasil penelitian Fauziyah (2013) memperlihatkan hubungan linier antara kemampuan metakognisi dengan hasil belajar kognitif tinggi pada pembelajaran TPS, dengan besarnya nilai kontribusi 32,478\%. Penelitian Nurisya (2017) juga menunjukkan hasil yang sama dengan kontribusi 72,560\%. Penelitian sejalan juga dilaporkan oleh Usman (2018) bahwa peningkatan keterampilan metakognitif akan disertai peningkatan hasil belajar kognitif tinggi. 
Metakognisi produk pembelajaran yang rendah juga memperlihatkan dampak lain, yaitu retensi siswa sebagai hasil pembelajaran. Hasil penelitian Fauziyah (2013) menunjukkan adanya hubungan yang kuat dengan besarnya kontribusi 46,133\%, sedangkan penelitian Nurisya (2017) menunjukkan kontribusi sebesar 35,965\%. Alasan rendahnya keterampilan metakognitif adalah penerapan pembelajaran di SMA yang mayoritas masih bersifat konvensional dan kurang memberdayakan keterampilan berpikir siswa. Penelitian yang dilakukan Fauziyah (2013) menunjukkan bahwa mayoritas pembelajaran di SMAN 6 Malang masih dilakukan secara konvensional dan bersifat teacher center. Penelitian lain Antika, (2015) juga menunjukkan fakta bahwa pembelajaran di SMAN 9 Malang khususnya pembelajaran biologi, kurang memberdayakan keterampilan berpikir siswa. Penelitian Nurisya, (2017) juga melaporkan bahwa penggunaan strategi pembelajaran di SMAN 7 dan SMAN 9 Malang masih minim.

Melalui strategi pembelajaran, upaya memberdayakan keterampilan metakognitif yang pada akhirnya berdampak pada hasil belajar kognitif tinggi dan retensi siswa penting dilakukan. Hasil penelitian Firda (2016) memperlihatkan adanya pengaruh pembelajaran PBL dipadu TAI dengan keterampilan metakognitif, berpikir kritis dan sikap spiritual siswa. Penelitian Anisah (2018) memperlihatkan peningkatan hasil belajar kognitif tinggi peserta didik yang dibelajarkan dengan PBL dipadu TAI. Penelitian lain Sulistyani (2012) juga menunjukkan bahwa pembelajaran model PBL dipadu TAI secara signifikan meningkatkan keterampilan berpikir kritis dan hasil belajar kognitif tinggi peserta didik. Berdasarkan uraian latar belakang, penelitian dengan judul "Pengaruh Pembelajaran Model PBL (Problem Based Learning) dipadu TAI (Team Assisted Individualization) terhadap Keterampilan Metakognitif, Hasil Belajar Kognitif Tinggi dan Retensi Siswa SMA" perlu dilakukan.

\section{METODE}

Penelitian jenis quasi experiment ini menggunakan rancangan Pretest-Posttest Nonequivalent Control Group Design. Kelas XI IPA 3 sebagai perlakuan menerapkan pembelajaran PBL dipadu TAI, kelas XI IPA 4 sebagai kontrol positif 1 menerapkan pembelajaran PBL, XI IPA 2 sebagai kontrol positif 2, menerapkan TAI, dan XI IPA 1 sebagai kontrol negatif, menerapkan konvensional. Keempat kelas diberikan pretes dan postes sehingga dapat dibandingkan hasilnya. Rancangan penelitian dapat dilihat pada tabel 1 .

\section{Tabel 1. Rancangan Eksperimen}

\begin{tabular}{lccc}
\hline \multicolumn{1}{c}{ Kelompok } & Pretest & Treatment & Posttest \\
\hline PBL dipadu TAI & $\mathrm{O}_{1}$ & $\mathrm{X}_{1}$ & $\mathrm{O}_{2}$ \\
PBL & $\mathrm{O}_{3}$ & $\mathrm{X}_{2}$ & $\mathrm{O}_{4}$ \\
TAI & $\mathrm{O}_{5}$ & $\mathrm{X}_{3}$ & $\mathrm{O}_{6}$ \\
Konvensional & $\mathrm{O}_{7}$ & $\mathrm{X}_{4}$ & $\mathrm{O}_{8}$ \\
\hline
\end{tabular}

\section{Keterangan:}

$\mathrm{X}_{1}$ : Perlakuan (pembelajaran dengan model PBL dipadu TAI)

$\mathrm{X}_{2}$ : Kontrol positif 1 (pembelajaran dengan model PBL)

$\mathrm{X}_{3}$ : Kotrol positif 2 (pembelajaran dengan model TAI)

$\mathrm{X}_{4}$ : Kontrol negatif (pembelajaran Konvensional)

$\mathrm{O}_{1}$ : Pelaksanaan pretes pada kelas pembelajaran dengan model PBL dipadu TAI

$\mathrm{O}_{2}$ : Pelaksanaan postes pada kelas pembelajaran dengan model PBL dipadu TAI

$\mathrm{O}_{3:}$ : Pelaksanaan pretes pada kelas pembelajaran dengan model PBL

$\mathrm{O}_{4}$ : Pelaksanaan postes pada kelas pembelajaran dengan model PBL

$\mathrm{O}_{5}$ : Pelaksanaan pretes pada kelas pembelajaran dengan model TAI

$\mathrm{O}_{6}$ : Pelaksanaan postes pada kelas pembelajaran dengan model TAI

$\mathrm{O}_{7}$ : Pelaksanaan pretes pada kelas pembelajaran Konvensional

$\mathrm{O}_{8}$ : Pelaksanaan postes pada kelas pembelajaran Konvensional

Penentuan sampel penelitian dilakukan secara acak (random sampling) melalui placement test. Instrumen penelitian, meliputi silabus, RPP, LKS, soal uraian 15 nomor, rubrik MAD, dan rubrik HBKT. Data berupa nilai postes dan pretes. Data dianalisis secara statistik melalui uji ANAKOVA dan uji LSD.

\section{HASIL}

\section{Pengaruh Pembelajaran Model PBL dipadu TAI Terhadap Keterampilan Metakognitif}

Hasil ANAKOVA pengaruh model terhadap keterampilan metakognitif tersaji pada tabel 2. Hasil uji anakova berdasarkan tabel 2 diperoleh $\mathrm{F}$ hitung sebesar 52,818 dengan $p$-value $0,00<a(a=0,05)$, artinya secara signifikan ada 
pengaruh model pembelajaran terhadap keterampilan metakognitif. Keterampilan metakognitif siswa yang dibelajarkan melalui model PBL dipadu TAI, PBL, TAI dan Konvensional secara keseluruhan berbeda nyata. Selanjutnya dilakukan uji LSD untuk mengetahui rerata selisih beda pembelajaran model PBL dipadu TAI terhadap model PBL, TAI, dan Konvensional dalam menjelaskan keterampilan metakognitif. Ringkasan hasil uji LSD keterampilan metakognitif disajikan pada tabel 3. Hasil ANAKOVA pengaruh model terhadap keterampilan metakognitif tersaji pada tabel 4.

Tabel 2. Uji Anakova Pengaruh Model Pembelajaran terhadap Keterampilan Metakognitif

\begin{tabular}{lrrrrr}
\hline Source & Type III Sum of Squares & Df & Mean Square & \multicolumn{1}{c}{ F } & Sig. \\
\hline Corrected Model & $5201,395^{\text {a }}$ & 4 & 1300,349 & 39,958 &, 000 \\
Intercept & 23572,866 & 1 & 23572,866 & 724,370 &, 000 \\
XKetMet & 109,377 & 1 & 109,377 & 3,361 &, 069 \\
Kelas & 5156,507 & 3 & 1718,836 & 52,818 &, 000 \\
Error & 3840,022 & 118 & 32,543 & & \\
Total & 407523,810 & 123 & & & \\
Corrected Total & 9041,417 & 122 & & &
\end{tabular}

a. $\quad$ R Squared $=, 575$ (Adjusted R Squared $=, 561$ )

Tabel 3. Uji LSD Keterampilan Metakognitif

\begin{tabular}{clrrrrr}
\hline No & Strategi & XKMETA & YKMETA & Selisih & KMETACor & Notasi LSD \\
\hline 1 & PBL+TAI & 26,6984 & 65,4921 & 38,7937 & 65,615 & a \\
2 & PBL & 27,9683 & 61,1429 & 33,1746 & 61,104 & b \\
3 & TAI & 29,0476 & 51,2698 & 22,2222 & 51,094 & c \\
4 & Konv & 27,013 & 50,4185 & 23,4055 & 50,502 & c \\
\hline
\end{tabular}

Hasil uji LSD menunjukkan bahwa keterampilan metakognitif siswa yang dibelajarkan melalui model PBL dipadu TAI secara signifikan lebih tinggi dibanding melalui model PBL, TAI dan konvensional. Rerata selisih beda pembelajaran model PBL dipadu TAI terhadap model PBL sebesar 7,38\%, PBL dipadu TAI terhadap TAI sebesar 28,42\%, dan PBL dipadu TAI terhadap konvensional sebesar 29,93\%.

Tabel 4. Anakova Pengaruh Model Pembelajaran terhadap Hasil Belajar Kognitif

\begin{tabular}{lrrrrr}
\hline Source & Type III Sum of Squares & Df & Mean Square & F & Sig. \\
\hline Corrected Model & $8007,618^{\mathrm{a}}$ & 4 & 2001,905 & 235,817 &, 000 \\
Intercept & 40978,515 & 1 & 40978,515 & 4827,108 &, 000 \\
XHBK & 105,996 & 1 & 105,996 & 12,486 &, 001 \\
Kelas & 7971,833 & 3 & 2657,278 & 313,017 &, 000 \\
Error & 1001,731 & 118 & 8,489 & & \\
Total & 636458,333 & 123 & & & \\
Corrected Total & 9009,350 & 122 & & & \\
\hline
\end{tabular}

a. R Squared $=, 889$ (Adjusted R Squared $=, 885$ )

Hasil uji anakova menunjukkan nilai $\mathrm{F}$ hitung sebesar 313,017 , dimana $p$-value $0,00<a(a=0,05)$, artinya secara signifikan model pembelajaran berpengaruh terhadap hasil belajar kognitif tinggi. Model PBL dipadu TAI, PBL, TAI dan Konvensional secara keseluruhan berbeda nyata dalam mempresentasikan nilai hasil belajar kognitif tinggi siswa. Selanjutnya dilakukan uji LSD untuk mengetahui rerata selisih beda pembelajaran model PBL dipadu TAI terhadap model PBL, TAI, dan Konvensional dalam menjelaskan hasil belajar kognitif tinggi. Ringkasan hasil uji LSD hasil belajar kognitif tinggi disajikan pada tabel 5. Ringkasan hasil analisis anakova pengaruh model pembelajaran terhadap retensi dapat dilihat pada tabel 6.

Tabel 5. Uji LSD Hasil Belajar Kognitif Tinggi

\begin{tabular}{|c|c|c|c|c|c|c|}
\hline No & Strategi & XHBEL & YHBEL & Selisih & HBELCor & Notasi LSD \\
\hline 1 & PBL+TAI & 35,6667 & 80,1667 & 44,5 & 80,276 & $\mathrm{a}$ \\
\hline 2 & PBL & 36,9444 & 79,0556 & 42,1112 & 79,049 & $\mathrm{a}$ \\
\hline 3 & TAI & 39,3889 & 64,3333 & 24,9444 & 64,105 & $b$ \\
\hline 4 & Konv & 35,6061 & 62,9798 & 27,3737 & 63,094 & $\mathrm{~b}$ \\
\hline
\end{tabular}


Hasil uji LSD menunjukkan bahwa hasil belajar kognitif tinggi siswa yang dibelajarkan melalui model PBL dipadu TAI secara signifikan lebih tinggi dibanding melalui model TAI dan konvensional, akan tetapi tidak berbeda nyata dengan model PBL. Rerata selisih beda pembelajaran model PBL dipadu TAI terhadap PBL sebesar 1,55\%, PBL dipadu TAI terhadap TAI sebesar 25,23\%, dan PBL dipadu TAI terhadap konvensional sebesar 27,23\%.

Tabel 6. Anakova Pengaruh Model Pembelajaran terhadap Hasil Belajar Kognitif

\begin{tabular}{|l|r|r|r|r|r|}
\hline Source & Type III Sum of Squares & Df & Mean Square & F & Sig. \\
\hline Corrected Model & $5556,180^{\mathrm{a}}$ & 4 & 1389,045 & 88,628 &, 000 \\
Intercept & 532,557 & 1 & 532,557 & 33,980 &, 000 \\
XRetensi & 23,217 & 1 & 23,217 & 1,481 &, 226 \\
Kelas & 1247,343 & 3 & 415,781 & 26,529 &, 000 \\
Error & 1849,375 & 118 & 15,673 & & \\
Total & 450205,556 & 123 & & & \\
Corrected Total & 7405,556 & 122 & & & \\
\hline \multicolumn{2}{|l|}{ a. Squared =,750 (Adjusted R Squared =,742) } \\
\hline
\end{tabular}

Hasil uji anakova berdasarkan tabel 6 diperoleh F hitung sebesar 26,529 dengan p-value 0,00 $<a(a=0,05)$, artinya ada pengaruh model pembelajaran terhadap retensi siswa. Retensi siswa yang dibelajarkan melalui model PBL dipadu TAI, PBL, TAI dan Konvensional secara keseluruhan berbeda nyata. Selanjutnya dilakukan uji LSD untuk mengetahui rerata selisih beda pembelajaran model PBL dipadu TAI terhadap model PBL, TAI, dan Konvensional dalam menjelaskan retensi siswa. Ringkasan hasil uji LSD retensi disajikan pada tabel 7.

Tabel 7. Uji LSD Retensi

\begin{tabular}{|c|c|c|c|c|c|c|}
\hline No & Strategi & XKMETA & YKMETA & Selisih & KMETACor & Notasi LSD \\
\hline 1 & PBL+TAI & 80,1667 & 68,3333 & $-11,8334$ & 67,067 & $\mathrm{a}$ \\
\hline 2 & PBL & 79,0556 & 64,4444 & $-14,6112$ & 63,339 & b \\
\hline 3 & Konv & 62,9798 & 56,6667 & $-6,3131$ & 57,889 & $\mathrm{c}$ \\
\hline 4 & TAI & 64,3333 & 50,8889 & $-13,4444$ & 51,915 & d \\
\hline
\end{tabular}

Hasil uji LSD menunjukkan bahwa retensi siswa yang dibelajarkan melalui model PBL dipadu TAI secara signifikan lebih tinggi dibanding melalui model PBL, TAI dan konvensional. Rerata selisih beda pembelajaran model PBL dipadu TAI terhadap PBL sebesar 5,89\%, PBL dipadu TAI terhadap TAI sebesar 29,19\%, dan PBL dipadu TAI terhadap konvensional sebesar $15,85 \%$.

\section{PEMBAHASAN}

Pengaruh Pembelajaran Model PBL dipadu TAI terhadap Keterampilan Metakognitif

Hasil analisis menunjukkan bahwa keterampilan metakognitif siswa yang dibelajarkan melalui model PBL dipadu TAI secara signifikan lebih tinggi dibanding melalui model PBL, TAI dan konvensional. Rerata selisih beda pembelajaran model PBL dipadu TAI terhadap model PBL sebesar 7,38\%, PBL dipadu TAI terhadap TAI sebesar 28,42\%, dan PBL dipadu TAI terhadap konvensional sebesar 29,93\%.

Sintak model PBL dipadu TAI yang terdiri dari sembilan langkah melatih keterampilan perencanaan, pemantauan, dan evaluasi terhadap diri peserta didik. Kegiatan merumuskan masalah melatih siswa untuk memahami suatu permasalahan yang sedang dihadapi, dan memahamai tujuan pembelajaran melalui diskusi kelompok. Kegiatan mengorganisasi siswa untuk meneliti melatih siswa untuk merencanakan langkah pemecahan masalah, mengumpulkan bahan materi yang mendukung pemecahan masalah, serta memprediksi masalah baru yang muncul sehingga dapat langsung dicari solusinya. Kegiatan melakukan investigasi, mengembangkan dan menyajikan hasil karya melatih siswa untuk memantau dan mengontrol perjalanan kognitifnya sendiri selama proses pembelajaran, mengkroscek setiap langkah apakah sudah sesuai dengan rencana dan tujuan atau sebaliknya. Selanjutnya, kegiatan Menganalisis dan mengevaluasi proses pemecahan masalah melatih siswa untuk mengevaluasi pemahamannya terhadap suatu konsep, mencari bagian konsep mana yang belum dipahami, langkah dan strategi pemecahan mana yang perlu diperbaiki dengan cara melakukan perbandingan, guna menjadi bahan perbaikan untuk pembelajaran selanjutnya. 


\section{Pengaruh Pembelajaran Model PBL dipadu TAI terhadap Hasil Belajar Kognitif Tinggi}

Hasil analisis menunjukkan bahwa hasil belajar kognitif tinggi siswa yang dibelajarkan melalui model PBL dipadu TAI secara signifikan lebih tinggi dibanding melalui model TAI dan konvensional, tetapi tidak berbeda nyata dengan model PBL. Rerata selisih beda pembelajaran model PBL dipadu TAI terhadap PBL sebesar 1,55\%, PBL dipadu TAI terhadap TAI sebesar 25,23\%, dan PBL dipadu TAI terhadap konvensional sebesar 27,23\%.

Pembelajaran model PBL dipadu TAI membantu siswa dalam mencapai tujuan aspek kognitif yang baik. Pembelajaran model PBL dipadu TAI menyediakan kegiatan yang dapat melatih keterampilan berpikir siswa, tidak hanya menghafal dan memahami saja, tetapi sampai pada kemampuan memecahkan masalah yang menuntut siswa untuk menghubungakan, menggabungkan, menganalisis, mengevaluasi, serta mengkreasi beberapa ide, gagasan, metode atau prosedur yang dipelajari untuk memecahkan masalah tersebut (Rusman, 2014). Kegiatan melakukan investigasi, mengembangkan dan mempresentaikan hasil karya, melatih keterampilan berpikir siswa untuk menghubungakan dan menggabungkan beberapa informasi, ide, gagasan, metode atau prosedur yang dipelajari untuk memecahkan masalah. Pada kegiatan ini siswa juga dilatih untuk menganalisis pemecahan masalah dengan cara memahami permasalahan itu sendiri, memahami keseluruhan informasi yang diperoleh, kemudian memilih informasi yang paling mendukung untuk memecahkan masalah.

Kegiatan menganalisis dan mengevaluasi proses pemecahan masalah melatih siswa untuk membandingkan beberapa informasi yang diperoleh, bisa dari kelompok lain, ataupun penguatan dari guru, sebagai bahan perbaikan terhadap pemecahan masalah yang telah dilakukan sehingga pada akhirnya diperoleh suatu kesimpulan yang benar dan jelas. Watson \& Glaser (1980) juga menjelaskan bahwa keterampilan evaluasi penting dimiliki oleh siswa, menjadikan siswa lebih kritis dalam menyikapi setiap permasalahan yang muncul. Kegiatan penugasan seperti membuat poster, powerpoint, animasi, model 3D (torso), melatih kreativitas siswa dalam menuangkan suatu ide, gagasan, konsep, pengetahuan dan unsur seni yang telah diperoleh kedalam bentuk yang nyata. Siswa yang memiliki pemikiran kreatif mampu menghasilkan beragam ide dan karya yang punya daya tarik tersendiri dengan cara mengkombinasikan, merubah atau menerapkan ide, prosedur, dan pengetahuan yang telah ada.

Keberhasilan pembelajaran model PBL dipadu TAI dalam memberdayakan hasil belajar kognitif juga didukung penelitian terdahulu. Penelitian yang dilakukan oleh Anisah (2018) dengan judul "Penerapan Model Pembelajaran Problem Based Learning Dipadu Dengan Team Assisted Individualization untuk Meningkatkan Hasil Belajar Siswa" menunjukkan hasil bahwa pembelajaran PBL dipadu TAI secara signifikan meningkatkan hasil belajar kognitif siswa SMA Negeri 3 Barabai, Kalimantan Selatan. Selanjutnya penelitian dari Firda (2016) dengan judul Penerapan Model Team Assisted Individualization Dipadu Problem Based Learning Disertai Penyusunan Portofolio untuk Meningkatkan Kemampuan Berpikir Kritis, Pemahaman Konsep, Sikap Spiritual, dan Keterampilan Siswa Kelas XI MIA 4 SMAN 6 Malang juga menunjukkan hasil bahwa pembelajaran model PBL dipadu TAI secara signifikan meningkatkan pemahaman konsep (hasil belajar kognitif) siswa.

Hasil belajar kognitif siswa yang dibelajarkan melalui model PBL dipadu TAI tidak berbeda nyata dengan model PBL. Berdasarkan urain yang telah dipaparkan, kunci keberhasilan dalam meberdayakan ranah kognitif tingkat tinggi ada pada lima sintaks pembelajaran, yaitu (1) orientasi masalah, (2) mengorganisasi siswa untuk meneliti, (3) melakukan investigasi, (4) mengembangkan dan mempresentasikan hasil karya, (5) menganalisis dan mengevaluasi proses pemecahan masalah. Baik model PBL dipadu TAI maupun model PBL memiliki lima sintaks tersebut sehingga keduanya sama-sama baik dalam memberdayakan ranah kognitif siswa.

\section{Pengaruh Pembelajaran Model PBL Dipadu TAI terhadap Retensi Siswa}

Hasil uji LSD menunjukkan bahwa retensi siswa yang dibelajarkan melalui model PBL dipadu TAI secara signifikan lebih tinggi dibanding melalui model PBL, TAI dan konvensional. Rerata selisih beda pembelajaran model PBL dipadu TAI terhadap PBL sebesar 5,89\%, PBL dipadu TAI terhadap TAI sebesar 29,19\%, dan PBL dipadu TAI terhadap konvensional sebesar $15,85 \%$. Pembelajaran model PBL dipadu TAI merupakan pembelajaran berbasis masalah yang diambil dari kejadian sehari-hari bahkan dialami oleh siswa. Pembelajaran model PBL dipadu TAI menyediakan kegiatan pembelajaran yang kontekstual, objek yang jelas dan kongkret sehingga mudah dipahami dan diingat oleh siswa (Degeng, 1989). Pelajaran yang dipahami dan diingat siswa akan lebih mudah ditimbulkan kembali setelah selang waktu cukup lama sekalipun.

Pembelajaran model PBL dipadu TAI berorientasi pada masalah yang kontekstual dan kongkret sehingga dapat melatih keterampilan otak siswa dalam memasukkan, menyimpan, dan menimbulkan kembali pengetahuan yang telah dipelajari. Kegiatan pembelajaran melatih siswa dalam menerapkan dan menggunakan pengetahuannya untuk memecahkan masalah kehidupan sehari-hari, sehingga pengetahuan tidak hanya sekedar menjadi pengetahuan, tetapi telah menjadi alat bantu untuk hidup. Pengetahuan yang demikian akan lebih lama tersimpan dalam ingatan siswa dibanding pengetahuan yang sekedar menghafal dan memahami (Murdock \& Bennet, 1962). Kegiatan memecahkan masalah juga melatih siswa menghubungakan dan menggabungkan beberapa pengetahuan lama dengan pengetahuan baru, melatih siswa dalam menimbulkan kembali pengetahuan yang tersimpan, menjadikan pengetahuan terus menerus digunakan yang dapat mencegah hilangnya pengetahuan dari ingatan (Degeng, 1989). 


\section{SIMPULAN}

Hasil penelitian menyimpulkan bahwa (1) keterampilan metakognitif siswa yang dibelajarkan melalui model PBL dipadu TAI secara signifikan lebih tinggi dibanding melalui model PBL, TAI, dan konvensional. Rerata selisih beda pembelajaran model PBL dipadu TAI terhadap PBL sebesar 7,38\%, PBL dipadu TAI terhadap TAI sebesar 28,42\%, dan PBL dipadu TAI terhadap konvensional sebesar 29,93\% (2) hasil belajar kognitif tinggi siswa yang dibelajarkan melalui model PBL dipadu TAI secara signifikan lebih tinggi dibanding melalui model TAI dan konvensional, akan tetapi tidak berbeda nyata dengan model PBL. Rerata selisih beda pembelajaran model PBL dipadu TAI terhadap PBL sebesar 1,55\%, PBL dipadu TAI terhadap TAI sebesar 25,23\%, dan PBL dipadu TAI terhadap konvensional sebesar 27,23\%, 3) Retensi siswa yang dibelajarkan melalui model PBL dipadu TAI secara signifikan lebih tinggi dibanding melalui model PBL, TAI, dan konvensional. Rerata selisih beda pembelajaran model PBL dipadu TAI terhadap PBL sebesar 5,89\%, PBL dipadu TAI terhadap TAI sebesar 29,19\%, dan PBL dipadu TAI terhadap konvensional sebesar 15,85\%. Pembelajaran model PBL dipadu TAI diterapkan dalam pembelajaran untuk melatih kemampuan metakognisi.

\section{DAFTAR RUJUKAN}

Anisah, Sumarmi, \& Astina, I. K. (2018). Penerapan Model Pembelajaran Problem Based Learning Untuk Meningkatkan Hasil Belajar Matematika SD. Primary: Jurnal Pendidikan Guru Sekolah Dasar, 7(1), 40. https://doi.org/10.33578/jpfkip.v7i1.5338

Antika, L. T., Corebima, A. D., \& Zubaidah, S. (2015). Pengaruh Model Pembelajaran Biologi berbasis Reading-Concept MapJigsaw terhadap Minat Baca dan Hasil Belajar Kognitif Siswa Kelas X SMA Malang. Symposium on Biologi Education, $150-156$.

Aprilia, F., \& Sugiarto, B. (2013). Keterampilan Metakognitif Siswa melalui Penerapan Model Pembelajaran Inkuiri Terbimbing pada Materi Hidrolis Garam. Unesa Journal of Chemical Education, 2(3), 36-41.

Ardila, C. (2013). Hubungan Keterampilan Metakognitif terhadap Hasil Belajar Biologi dan Retensi Siswa Kelas X dengan Penerapan Strategi Pemberdayaan Berpikir melalui Pertanyaan (PBMP) di SMAN 9 Malang. Skripsi tidak diterbitkan. Universitas Negeri Malang, Malang.

Basith, A., Corebima, A. D., \& Zubaidah, S. (2014). Hubungan Antara Keterampilan Metakognitif Dan Pemahaman Konsep Biologi Siswa Kelas X pada Penerapan Strategi Problem-Based Learning dan Reciprocal Teaching di SMA Brawijaya Smart School Malang. Proceeding Biology Education Conference, 11(1), 818-824.

Corebima, A. D. (2016). Pembelajaran Biologi di Indonesia Bukan Untuk Hidup. Seminar Nasional XIII Biologi, Sains, Lingkungan, dan Pembelajarannya di Pendidikan Biologi FKIP UNS, 13(1), 8-22.

Degeng, I. N. S. (1989). Ilmu Pengajaran Taksonomi Variabel. Jakarta: Departemen Pendidikan dan kebudayaan Direktorat Jendral Pendidikan Tinggi Proyek Pengembangan Lembaga Pendidikan Tenaga Kependidikan.

Emily, R. L., \& Michaele, V. (2012). No Title. National Council on Measurement in Educatioan: Vancouver, B.C.

Fauziyah, D. R., Aloysius, D. C., \& Zubaidah, S. (2013). Hubungan Keterampilan Metakognitif Terhadap Hasil Belajar Biologi Dan Retensi Siswa Keas X dengan Penerapan Strategi Pembelajaran Think Pair Share di SMA Negeri 6 Malang. Jurnal Pendidikan: Teori, Penelitian, dan Pengembangan, (January), 1-16.

Firda, A. (2016). Penerapan Model Team Assisted Individualization Dipadu Problem Based Learning Disertai Penyusunan Portofolio untuk Meningkatkan Kemampuan Berpikir Kritis, Pemahaman Konsep, Sikap Spiritual, dan Keterampilan Siswa Kelas XI MIA 4 SMAN 6 Malang. Skripsi tidak diterbitkan. Universitas Negeri Malang, Malang.

Murdock, J., \& Bennet, B. (1962). The Serial Position Effect of Free Recall. Journal of Experimental Psychology, 64(5), 482488.

Nurisya, K., Corebima, A. D., \& Rohman, F. (2017). Analisis Perbandingan Hubungan Antara Keterampilan Metakognitif Terhadap Hasil Belajar dan Retensi Siswa SMA pada Pembelajaran Biologi Berbasis PBL. Jurnal Pendidikan: Teori, Penelitian, dan Pengembangan, 2(2), 246-251.

Peters, M. (2000). Does Constructivist Epistemology Have a Place in Nurse Education? Journal of Nursing Education, 39(4), 70-166.

Rusman. (2014). Model-model Pembelajaran (Mengembangkan Profesionalisme Guru). Jakarta: Raja Grafindo Persada.

Sholihah, M., Zubaidah, S., \& Mahanal, S. (2015). Keterampilan Metakognitif Siswa SMA Negeri Batu Pada Mata Pelajaran Biologi. Prosiding Seminar Nasional Biologi / IPA dan Pembelajarannya, 1(4), 1669-1676.

Sulistyani, N. (2012). Implementasi Pembelajaran Berbasis Masalah Dipadukan dengan Model Pembelajaran Kooperatif Tipe TAI (Team Assisted Individualization) untuk Meningkatkan Kemampuan Berpikir Kritis Matematis Pada Siswa SMPN 2 Sentolo Kelas IXA. Prosiding Seminar Nasional Matematika dan Pendidikan Matematika FPMIPA UNY, 65(2), 978979.

Suratno. (2010). Pemberdayaan Keterampilan Metakognisi Siswa dengan Strategi Pembelajaran Jigsaw-Reciprocal Teaching (JIRAT). Jurnal Ilmu Pendidikan, 17(2), 150-156. 
Trilling, B., \& Fadel, C. (2012). No Title21 st Century Skills : Learning for Life in Our Times. New York City: John Wiley \& Sons Inc.

Usman, A. A., Hala, Y., \& Pagarra, H. (2018). Hubungan Antara Kemampuan Metakognisi, Motivasi, dan Kesiapan Mental dengan Hasil Belajar Biologi Siswa Kelas XI IPA SMA Negeri di Kabupaten Gowa. Journal of Biological Education, $2(1), 47-56$.

Watson, G., \& Glaser, E. M. (1980). Watson-Glaser critical thinking appraisal. New York City: The Psychological Corporation.

Zubaidah, S. (2016). Keterampilan Abad Ke-21: Keterampilan yang Diajarkan melalui Pembelajaran. Seminar Nasional Pendidikan, 2(2), 1-17. https://doi.org/10.1021/acs.langmuir.6b02842 